\title{
EDUCAÇÃO E AS ASSOCIAÇÕES SINDICAIS EM SOROCABA NO INÍCIO DO SÉCULO XX ${ }^{1}$
}

\author{
Jefferson Carriello do Carmo \\ Universidade Católica Dom Bosco - UCDB \\ jefferson@ucdb.br
}

\begin{abstract}
RESUMO
O objetivo do texto foi verificar, através das associações sindicais na cidade de Sorocaba, entre o final do século XIX inicio do século XX, a questão da educação no contexto do processo de industrialização e da imigração. Num primeiro momento verificou-se a inserção das correntes socialista e anarcossindicalista, na cidade de Sorocaba e suas contribuições para organização e formação do operariado sorocabano. Quanto a imigração, constatou-se que essa propiciou ao operariado, através de novas idéias, o impulso para a organização operária em sindicatos, onde se processava a luta de classe e a conquista pelo direito a educação. Por fim, constatou-se que a consciência sobre a educação estava norteada pelos ideais libertários, cuja referência está na educação integral e a transformação social através das formas institucionalizadas de instrução operária.
\end{abstract}

Palavras-chave: Socialistas, Anarcossindicalista, Educação, Política, Trabalho, Industrialização.

\section{EDUCATION AND TRADE UNIONS IN SOROCABA AT THE BEGINNING OF THE TWENTIETH CENTURY}

\begin{abstract}
The objective was to verify through the text of trade unions in the city of Sorocaba between the late nineteenth early twentieth century the issue of education in the context of industrialization and immigration. At first noted the creation of associations of current socialist and anarcho-syndicalists and their contributions to the organization and training of the workers Sorocaba. As immigration has found that this led to labor through new ideas to push for organized labor unions in that processed the class struggle and achievement for the right to education. Finally, it was found that the awareness of education were guided by libertarian ideals, whose reference is a comprehensive education and social transformation through the institutionalized forms of education workers.

Keywords: Socialists, Anarcho-Syndicalist, Education, Politics, Labor, Industrialization.
\end{abstract}

\section{Considerações iniciais}

O que se pretende, com esse tema, é verificar através das associações sindicais na cidade de Sorocaba, entre o final do século XIX inicio do século XX, a questão da educação no contexto do processo de industrialização e da imigração. Essa preocupação centrou-se no contexto da atividade industrial, na urbe sorocabana e como as condições de trabalho contribuíram, visivelmente, para que novos costumes e rotinas fossem determinantes à cidade, no aspecto educacional.

Verifica-se que na gênese dessas atividades já havia contradições entre a nascente burguesia industrial e os operários fabris. Essas oposições ocorrem entre a burguesia industrial originária das antigas elites comerciais e o operariado arregimentado dentre os naturais da cidade e os imigrantes que afluíam das lavouras para os meios urbanos, vindos dos tradicionais países de imigração que abasteceram o país. 
Quanto aos imigrantes verificou-se, através dos anúncios da imprensa sorocabana ${ }^{2}$, que no final do século XIX a cidade, impulsionada pelo avanço industrial, passou a atrair os italianos e alemães que exploravam o comércio urbano através das manufaturas e pela diversificação dos investimentos, como se pode perceber a partir de alguns exemplos, como dos italianos Alferio Malzone (calçados); Antonio Faizano (macarrão); Mathias Baddini (café em pó); Domenico Guli (massas); José Luchesi (calçados); Francisco Matarazzo (banha); dos alemães Augusto Boemer, Faust e Schimming, Luiz Bücher de Lausberg e Raszl, que mantinham as fábricas de cerveja; Eduardo Müller (fábrica de colchões) e Joana Katzer (louças). Juntamente com esses estrangeiros a cidade atraía pessoas de outros locais ocorrendo a diversificação de serviços. Muitos desses imigrantes e comerciantes começam a investir seu capital em outras atividades, a partir dos anos de 1880, propiciando as primeiras instalações das indústrias de grande porte que era representada pela indústria têxtil (Cf. ALMEIDA, 2002; RIBEIRO, 1988). Na gênese desse processo de implantação das fábricas, na cidade de Sorocaba, sob o ponto de vista do processo de trabalho, ocorrem algumas implicações que privilegiam a fábrica nas formas de sujeição do trabalho ao capital e a oposição operária tendo como respaldo organizador as associações sindicais. Nessa relação de sujeição e oposição, no espaço da dominação do capital sobre o trabalho, se desenvolvem e se adquirem mecanismos que se explicitam na imposição de uma nova divisão de trabalho através da sua desqualificação, na determinação do salário e na duração do tempo de trabalho. É nessa relação que os operários criavam as suas formas de resistência e de insubordinação aos ditames do capital. Com as transformações da produção, da nova divisão do trabalho, o estabelecimento das fábricas de tecido e a mecanização do trabalho há o surgimento de várias organizações associativas e movimentos operários ligados diretamente à produção. No caso de Sorocaba podemos citar os movimentos e associações ligadas à produção, na sua maioria compostas por imigrantes europeus, que trazem do Velho Mundo as novas idéias que rondavam os meios operários: A Conquista do Bem, do Partido Democrata-Socialista, a Societá Operaria Italiana di Mutuo Soccorro e Beneficenza, a Liga de Resistência Operária, a Sociedade Beneficente dos Chapeleiros, o Sindicato de Resistência dos Tecelões, Círculo Socialista e outras, nas quais se processam manifestações, cujo cerne girava em torno das conquistas dos direitos de participação civil e a resistência à exploração.

Neste contexto, da implantação do processo de industrialização na cidade de Sorocaba, as associações de correntes socialistas e anarcossindicalistas firmaram-se cada vez mais com as novas características que lhe eram conferidas: organizar e formar o operariado sorocabano. Embora não possamos deixar de considerar que as divergências entre essas correntes, oriundas das lutas ideológicas travadas na capital do Estado, foram trazidas para a cidade, que diante de uma inoperância e talvez, da quase ausência dos socialistas no meio operário local os anarcossindicalistas e anarquistas tomaram o lugar dos socialistas nas lutas operárias. (Cf. ARAUJO NETO, 2005)

Por fim, verificou-se a relevância que essas associações davam a educação, embora haja registros, na imprensa operária Sorocabana, que identificavam e reconheciam as dificuldades encontradas pelo operariado nascente para freqüentar a escola devido às muitas horas de trabalho, bem como a longa duração das jornadas de trabalho que os impossibilitavam, em sua grande maioria, de freqüentarem as escolas noturnas. Lembra-nos Pinheiro e Hall (1979) que a importância da educação e da instrução dada pelo movimento operário era tão grande que uma das grandes reivindicações norteada por esse movimento era a redução da jornada de trabalho para $8 \mathrm{~h}$ ou pelo menos para $10 \mathrm{~h}$ diárias sendo que essa era uma das exigências principais do movimento operário brasileiro. Essa constatação é visível desde o Primeiro Congresso Socialista de 1892, no Rio de Janeiro. 


\section{ASSOCIAÇÕES SINDICAIS EM SOROCABA: SOCIALISTAS E ANARCOSSINDICALISTAS}

$\mathrm{Na}$ cidade havia imigrantes das diversas nacionalidades sendo eles, em sua maioria, europeus que traziam em seus ideários as novas opiniões presente nos meios operários e teriam como objetivo fixar o nacionalismo e o patriotismo em relação à terra natal. (Cf. RODRIGUES, 1984). No Brasil, criaram associações, nas quais realçavam suas próprias opiniões quanto aos direitos sociais. Isso é possível verificar na historiografia sorocabana e na história do movimento operário no Brasil onde encontramos relatos das lutas dos imigrantes que vieram como colonos para as fazendas de café do Estado de São Paulo (BONADIO, 2004; ARAUJO NETO, 2005, CAVALHEIRO, 2001; MARTINS, 1981; RODRIGUES, 1974; SILVA, 1976, dentre outros).

As primeiras alusões sobre as associações sindicais em Sorocaba foi a dos socialistas, no ano de 1890. Essa menção aparece através de notícias e artigos em revistas, que incentivava a organização operária na região (CARMO, 2006). Os redatores dessas revistas, através da imprensa local, consideravam que a cidade era um local que guardava características próprias, "onde grande parte da população vive do resultado de pequenas indústrias". Porém, nada leva a crer que essa associação tenha se organizado no ano de 1890. (ARAUJO NETO, 2005, p. 49).

Embora haja registros encontrados que demonstram que as primeiras manifestações da criação do Diretório Socialista são de 1890, na historiografia Sorocabana não há confirmação dessa data. $\mathrm{O}$ que se constata nesse período e nos anos posteriores é um socialismo que absorvia pessoas de alto nível econômico e que estavam acima de qualquer ato que viesse contrariar as atividades industriais em sua gênese. Há vários registros que indicam que no ano de 1896, com uma grande festa, funda-se a Sociedade Beneficente dos Empregados da Companhia União Sorocabana e Ituana dos operários de Sorocaba, mas, como esclarece Araujo Neto, ela tem um caráter eminentemente eleitoreiro. (2005, p. 49-50)

Em 1896, funda-se uma grande sociedade operária na cidade; a Sociedade Beneficente dos Empregados da Cia. União Sorocabana e Ituana. Houve grande festa e para ela convidaram-se associações, autoridades, como o Juiz de Direito da Comarca, e pessoas de "reconhecida honestidade". Houve batismo do estandarte da Sociedade, sendo ela apadrinhada por S. Excia. Reverendíssima, bispo conde de Sto. Agostinho. A festa foi realizada em salão da Fábrica Sta. Rosália. A Sorocabana cedeu trens "a toda hora" para transportar pessoas da estação até a fábrica. À noite, houve leilão de prendas. Durante o dia aconteceu o desfile da associação e de seus convidados por algumas ruas do centro da cidade.

Pode-se especular que, o convite às autoridades e notáveis da cidade e região, serviria para demonstrar que os operários eram submissos e respeitadores da ordem estabelecida. Desviaria, por conseguinte, olhares preconceituosos e desconfiados da sociedade e das autoridades. Mesmo a presença das autoridades em eventos como esse, representaria para o sistema, que se reafirmava seu poder e seus princípios de hierarquia social.

Em 1897, o jornal A Voz do Povo, de 29 de janeiro do decorrente ano, dá a conhecer o surgimento de um "órgão legítimo" para a defesa da classe operária de Sorocaba, A Conquista do Bem que se apresentava como órgão do Partido Democrata Socialista na cidade. (BONADIO, 2004) 
Segundo Bonadio (2004), esse artigo do jornal procura envolver os "socialistas sorocabanos" em questões políticas. Neste mesmo ano, Dario de Oliveira, que era o diretor do jornal a A conquista do Bem, apresentava esse órgão como oficial do Partido Democrata Socialista na cidade. Em seu primeiro número declara:
"O Nosso Jornal"
"Na arena do jornalismo brasileiro, aparece hoje mais um campeão denodado que vai caminhar na vanguarda desse exército poderoso e digno que se chama operariado.
Desenrola sobranceiro pendão do socialismo e alista-se nas fileiras mais avançadas desse partido de oprimidos, que, um dia, hão de fazer os cadafalsos tingir-se com o sangue azul dos grandes senhores. Sem lutas titânicas, sem guerras fratricidas, o socialismo há de aparecer em breve, há de fazer acabar de vez com os tempos de D. João VI, a encarnação do mal, de Catharina e Carlos IX , (...) de Leão X, tempos esses que são os mesmos em que vivemos, porque o fanatismo tem feito dos pobres, escravos, e dos aristocratas dos trabalhadores uns grilhetas!
Não pretendemos enganar o mundo, creiam.
O nosso fim, a nossa missão é por-nos ao lado dos grandes lutadores, porque o socialismo na sua essência há de ser a água lustral que purificará as Madalenas e redimirá os Lázaros.
(...)
Aos operários dignos, o nosso apoio; aos corruptos desprezo."
"A Redação". (BONADIO, 1992)

A fim de reforçar a incursão dos socialistas na cidade de Sorocaba, ainda é possível verificar, pela imprensa, que no ano de 1897 surge, dentre outras, a publicações da revista $O$ Fim do Século, cuja finalidade política foi destinada a propagandear o socialismo, sendo redigida por Arthur Silva, pseudônimo de Isaltino G. Costa. Em seu subtítulo aparece: em favor do Socialismo, Cosmopolitismo e Espiritismo. Abaixo, o programa da revista:

Somos um novo combatente que se alista voluntário na legião sacratíssima
dos que lutam pela verdadeira democracia, pela liberdade do povo, pela
felicidade do gênero humano. O nosso programa é resumido, como é vasto o
campo de nossas lutas. Desenrolamos a nossa bandeira, e fazemos com o
desejo ardente de trabalhar pela conquista inteira de todas as reformas que
visam fins benéficos salutares a todo o gênero humano. As idéias modernas
que têm revolucionado os povos no turbilhão deste findar de século, serão
tratadas e defendidas nestas colunas. Combateremos a favor das idéias
político-sociais que buscam a solução do problema social dispensando ao
operário liberdade e direitos. A bem do Cristianismo sob a teoria de Kardec
também nos propomos a pugnar. Guerrearemos os preconceitos do
nativismo, como prejudiciais à Pátria e à Humanidade. Batalharemos pela
completa queda da influência dos jesuítas como nociva à sociedade e à
família. É este o nosso programa. (O Fim do Século. Apud. ARAUJO
NETO, 2005, p. 54)

Com a preocupação de tornar visíveis as propostas socialistas, a revista, em vários momentos, coloca em evidência o que estavam pretendendo.

(...) Batalhamos pela Reforma Social; queremo-la ardentemente. Ela é a incógnita da matemática do pensamento, procurada para a solução do melhoramento social. O socialismo nada mais deseja do que a sagrada 
reivindicação dos direitos (...) se tendes compaixão a essas criaturinhas tuberculosas e enfezadas que morrem nas viciadas atmosferas das fábricas auxilie-nos. Convicto de sua força o socialismo, não pela violência, mas pela evolução, progride com rapidez vertiginosa (O Fim do Século. Apud. ARAUJO NETO, 2005, p 55)

Segundo Araujo Neto (2005), essa revista tinha um caráter extremante passivo quanto a um posicionamento político frente a classe operária; em suas publicações visavam reformas e benefícios a todo gênero humano.

Suas "reformas que visam fins benéficos a todo o gênero humano" mostram a imprecisão e passividade política que assumia, talvez apontando para objetivos eleitorais como vimos no jornal anterior. A própria forma com a qual foi tratado o operariado - "criaturinhas tuberculosas e enfezadas" demonstra que a origem social do redator não era proletária, como não era exatamente para essa classe que se destinavam seus artigos. Deixa nítida, ao contrário de A Conquista do Bem, que tinha uma posição ambígua nessa parte, sua aversão à violência: "não pela violência, mas pela evolução". O reformismo dessa revista mesclava-se em partes, com a filantropia social de meados do século XIX tratada por Marx, dando-lhe às vezes aparência burguesa. Seu cosmopolitismo que combatia "os preconceitos do nativismo" era uma versão amena do que poderia ser o internacionalismo proletário. Pois afinal, quando se referia à evolução, tinha de aceitar propostas de relações amplas com todo o mundo, ainda que politicamente fossem relações tênues e imprecisas. Filosófica e culturalmente poderiam ser ou pretendiam ser bastante ativas (ARAUJO NETO, 2005, p. 55).

Em seu conteúdo havia um determinado ecletismo de posição intelectual caracterizado pelas mais variadas publicações e pelas diversas formas de opinião, sem observância alguma de uma linha rígida de pensamento. Há desde as publicações de socialistas, como as de Alicare Cypriani, os textos de anarquistas como Kropotkin - A Conquista do Pão -, até as publicações religiosas kardecistas.

O próprio subtítulo da revista traz este ecletismo, Em favor do Socialismo, Cosmopolitismo e Espiritismo, que reúne elementos doutrinários de origens diversas que não chegam a se articular em unidade sistemática consistente. Embora não estivesse claro o posicionando político partidário da revista, é evidente a aversão ao jesuitismo e a defesa por escolas leigas e gratuitas, que foi um posicionamento também assumido pelos anarcossindicalistas.

Há várias evidencias que o socialismo em Sorocaba, após inúmeras investidas, não conseguiu firma-se na cidade, embora haja diversas publicações que trazem a cogitação da criação de Diretórios e Centro Socialista. No jornal A Conquista do Bem a menção da criação de um Centro Socialista, citado, também pelo Almanaque de Sorocaba de 1903, como sociedade política. Há registros de várias sociedades políticas e operárias em Sorocaba entre 1902 - 1904. (Cf. Almanach de Sorocaba, 1903; Almanach de Sorocaba 1904).

A presença socialista é, ainda, marcada por algumas conferências nos anos de $1902 \mathrm{e}$ 1903, sendo os oradores: "Benjamin Motta (1902); Paschoal Cilento (jan. 1903) e Alceste de Ambrys (mar. 1903)”. Houve festas promovidas pelos operários, cuja finalidade era comemorar o "natal dos deserdados". O que favoreceu, ainda que em pequenas proporções, uma tomada de consciência por parte do operariado e, também, preparou um ambiente propício para a aceitação de novos ideais políticos, voltados à questão social.

Nos anos vindouros a estes ocorre o crescimento do movimento operário devido ao aumento da massa proletária. Há estudos que identificam que as próprias condições materiais 
propiciavam uma maior agitação do meio proletário. Porém, foram os anarcossindicalistas e os anarquistas que assumiram a vanguarda do movimento, conquanto os socialistas continuassem presentes na cidade.

Quanto aos anarcossindicalistas, há registros de que a Liga Operária Sorocaba anarcossindicalistas, em 1906, estava ativa em Sorocaba, embora não tenha enviado delegados próprios da cidade para a $1^{a}$ Conferência Operária de São Paulo, realizada nos dias 6, 7 e 8 de dezembro, mas sugeriram os nomes de Edgar Leuenroth e Conerado Corradi, que eram anarquistas (RODRIGUES, 1969, p. 180).

Foi no período de 1909 que foi divulgada a presença dos anarcossindicalistas em Sorocaba, que contribuíram, significativamente, para a organização dos operários locais. Os registros dessa organização e suas ações estão postas no jornal $O$ Operário ${ }^{3}$ publicado no período de julho de 1909 a janeiro de 1913. Em seu conteúdo, há registros do combate ao capitalismo e o trabalho de conscientização dos operários quanto à condição operária. Essa condição de luta e de formação da classe operária está presente já nos primeiros números desse jornal e segue algumas determinações apresentadas no Primeiro Congresso Operário Brasileiro ocorrido na cidade do Rio de Janeiro entre os dias 15 a 22 de abril de 1906.

Em seu primeiro número já há indicações da influencia do Congresso no Jornal quanto ao posicionamento político partidário dos anarcossindicalistas em Sorocaba (O Operário, 18/07/1909, Anno I, n. 1, p. 1). A seguir o jornal expõe sua posição ideológica e a sua finalidade, tornando-se mais evidente nos números posteriores em que acentua as denuncias dos desmandos do capitalismo pela classe operária e, ao mesmo tempo, visa reunir o proletariado através da união e conscientização.

O jornal segue as orientações postas pelo Primeiro Congresso Operário Brasileiro de 1906 quanto à participação eleitoral do proletariado por entender que esse caminho era uma forma burguesa de ilidi-los. Denunciou o processo eleitoral veemente pelo uso dos empresários em época de eleições, de "coagirem os empregados a votarem no candidato que lhes é mais simpático". De acordo com a tendência nacional, e mesmo internacional, do anarcossindicalismo da época, o jornal $O$ Operário seguiu em situações contrárias à participação eleitoral do proletariado, sempre indicando ser uma via eleitoral invariavelmente burguesa, de ludibriação da classe operária. Denunciou em diversas oportunidades o hábito dos empresários em época de eleições, de "coagirem os empregados a votarem no candidato que lhes é mais simpático". Tal situação encontrava plena correspondência com as características eleitorais que vigoravam durante a chamada República Velha, o que demonstrava, de maneira geral, a impossibilidade de se derrotar eleitoralmente o grupo político dominante, quase sempre representado pelo Partido Republicano Paulista - PRP, valendo este caso também para grupos políticos burgueses dissidentes. Quanto aos procedimentos diante do encaminhamento das lutas políticas, da fundação de associações de resistência e orientações políticas, os anarcossindicalista trazem algumas orientações:

(...) Devemos desprezar as lutas políticas de partidarismo apaixonado que para nós é sempre prejudicial, pois sendo o sindicalismo um todo inteiramente à parte, inteiramente econômico, assim deve ser (O operário, 18/07/1909, Anno I, n. 1, p. 1)

(...) É pois uma necessidade imprescindível a fundação de uma associação de resistência baseada nos moldes do sindicato federativo. A federação é a base fundamental da união, da propaganda ideal do socialismo, da resistência de combate em favor do trabalho, e contra o capital (...) Concentrai-vos operários! (O Operário, 20/08/1911, Anno I, n. 1, p. 1)

Os Syndicatos

O primeiro desejo dos que constituem um sindicato, é criar uma força capaz de resistir às exigências patronais. Quer dizer: o agrupamento forma-se 
naturalmente, no terreno econômico, sem a necessidade duma idéia préconcebida; são interesses que estão em jogo e todos os operários que têm interesses idênticos aos do agrupamento, podem filiar-se nele, sem necessidade de declararem quais são as suas idéias em matéria filosófica, política, ou mesmo religiosa (O Operário, 26/11/1911, Anno III, n. 110, p. 1) Oreste Ristori

Esteve nesta cidade, e deu-nos o prazer de ouvir a sua eloqüente palavra, o ilustre orador cujo nome nos serve de epígrafe, discutindo sobre vários pontos referentes à escola moderna, demonstrando de um modo claro e preciso as vantagens do ensinamento único racional, o único verdadeiro, o único digno de ser ministrado aos nossos filhos, para que não sejam amigos de padres e de confessionários (O Operário, 24/04/1910, Anno I, n. 31, p. 2).

Nesse período, havia na cidade de Sorocaba, como também em todo o país, a finalidade de se formar uma federação sindical forte, (Cf. KOVAL, 1982; HARDMAN, LEONARDI, 1991.). Esse alvo encontra o seu eco no grande congresso operário que viria a se realizar no país em 1913, embora seja possível verificar essa preocupação desde o Congresso Operário de 1906, em que foi formada a Confederação Operária Brasileira (PINHEIRO e HALL, 1979, p. 41;). O que estava em jogo, na cidade, era o momento de fortalecimento da federação, para levar-se adiante dos projetos anarcossindicalistas em Sorocaba.

Para os anarcossindicalistas, nesse período, a questão educacional foi uma prioridade, mas que, também estavam no centro de interesse dos industriais por razões ligadas as mudanças econômicas na cidade.

\section{A LUTA OPERÁRIA PELA EDUCAÇÃO EM SOROCABA}

A questão da educação para o operariado sorocabano, nas primeiras décadas do Século $\mathrm{XX}$, foi uma luta que não só se restringia as questões educacionais, como também a própria organização da classe. A organização era fator preponderante para que os trabalhadores pudessem freqüentar as escolas noturnas, o que não ocorria devido a forma como estava organizado o trabalho nas indústrias têxteis (CARMO, 2006).

Ao mesmo tempo em que a empresa proporciona aos menores trabalhadores a "condição" de terem o trabalho, a expropriação dos salários, tirados pela fábrica na forma de descontos, como registra o jornal $O$ Operário, vem caracterizar, mais uma vez, outro mecanismo de exploração já denunciado pela imprensa local.

A jornada de trabalho que envolvia os menores era outro aspecto denunciado pelo jornal. Havia longas jornadas de trabalho que se estendiam de 12 a 15 horas diárias, num regime intenso, havendo paradas de meia hora, em média, para o almoço. Nessa longa jornada há três fatores presentes degradantes, quando olhados pela ótica humanística. Primeiro, o aumento do processo de exploração advindo do aumento da jornada de trabalho, em que tudo era feito em nome do progresso. Segundo, essa condição esgotava a saúde das crianças, que cresciam macilentas por causa da insalubridade do local de trabalho e da má alimentação. (Apud. Gazeta do Além Ponte. 14/04/1992)

Outro aspecto denunciado pelo jornal eram os castigos corporais aos menores, realizados pelos contramestres e fiscais das seções da Fábrica Nossa Senhora da Ponte.

(...) Fez-se ouvir em primeiro lugar o nosso amigo Antônio Argento que levantou um enérgico protesto sobre o modo brutal e desumano, porque na Fábrica N.S. da Ponte castigam os menores, tendo se dado em dias passados o fato altamente 'digno e louvável' de um Sr. Eloy Ribeiro, preposto do Sr. Cugnasca, ter agarrado um pela garganta, de modo a causar-lhe asfixia, 
sendo necessário recorrer-se de pronto à farmácia! Onde foi medicado $(\mathrm{O}$ Operário. Anno I, nº 10, 12/12/1909, p. 1).

A denúncia desses abusos e a contratação de menores para trabalhos noturnos eram anunciados pela imprensa operária contra a Fábrica Fonseca.

(...) Entrada às 6 horas da tarde;

Saída às 3 horas da madrugada;

Como todos sabem na Fábrica Fonseca, turmas de operários trabalham de noite e entre essas turmas existem crianças, que por necessidade ou desleixo dos pais fazem parte das mesmas. (O Operário. Anno III, $\mathrm{n}^{\mathrm{o}}$ 122, 24/12/1911, p. 1)

Verificou-se, ainda, que, além de castigos corporais impostos aos menores, havia as longas jornadas de trabalho, a má alimentação, o cansaço em demasia a que eram sujeitados os pequenos operários de 10 e 12 anos, ajudantes dos principais operários, propensos também aos diversos acidentes, algumas vezes graves, como é noticiado em Desastre na fábrica $S$. Paulo.

O menor Euclydes Brasiliense de 12 anos de idade, C...) trabalhava na engomadeira, quando por descuido, muito natural das crianças, viu-se preso, pelo braço direito no cilindro da máquina (...) fazemos um justíssimo pedido de não se suspender ao nosso companheirinho o seu salário, enquanto estiver preso ao leito de dor. (O Operário. Anno II, nº 44, 24/10/1910, p. 03)

A descrição das condições a que estavam submetidas as crianças nas relações de trabalho nas fábricas também era objeto de denúncia do jornal, como é registrado em $A$ infância operária de Sorocaba.

É triste para mim e outros que como eu prezam em ser sorocabanos, é triste, muito triste de ver uma multidão de pequenos, completamente analfabetos, trabalharem numa escura fábrica, desde às $5 \mathrm{~h}$ da manhã até às $7 \mathrm{~h}$ da noite, ganhando 250 réis e 300 réis durante essas horas! (O Operário. Anno II, $\mathrm{n}^{\circ}$ $44,24 / 10 / 1910, p ; 2)$

A condição das longas e estafantes jornadas de trabalho a que eram submetidos os menores, provavelmente, levava à distração e ao cansaço, causas dos acidentes.

No $O$ Operário, verifica-se que, além das jornadas de trabalho de 12, 13, 14 e até 15 horas diárias, como era o caso das fábricas Santa Maria, Santa Rosália e Fonseca, em alguns casos acontecia também o chamado "serão", que era estendido até a madrugada. Entre outras coisas, essas jornadas de trabalho muito longas, impediam que os menores em serviço freqüentassem as escolas noturnas que existiam na época:

As fábricas de tecidos Santa Maria e Santa Rosália trabalham até oito e meia da noite (...), a de Nossa Senhora da Ponte até às 7 h, a Fábrica de Chapéus até às 5:30h da tarde.

As escolas noturnas criadas e mantidas pelo governo do Estado, segundo o regulamento, devem abrir-se às 6 horas da tarde, fechando-se às 9 da noite. (O Operário. Anno II, nº 53, 02/10/1910, p. 01) 
No Primeiro Congresso Socialista Brasileiro de 1892 constata-se a redução da jornada de trabalho, cuja finalidade era permitir que os trabalhadores e seus filhos pudessem freqüentar as escolas noturnas (PINHEIRO, HALL, 1979: 28-29, vol. I)

No início do Século XX, em Sorocaba, constata-se, pela imprensa local, que o número de escolas noturnas era reduzido em menor quantidade o que impossibilitava os operários e seus filhos a freqüentarem estes locais de ensino. Segundo Araújo Neto, (2005, p. 41 "havia duas importantes escolas operárias noturnas, uma no distrito de Votorantin e outra dentro da propriedade Santa Rosália. Existiam ainda outras escolas menores mantidas por instituições filantrópicas. Inclusive, mantidas pela maçonaria, representada em Sorocaba pela Loja Perseverança III".

É notável o distanciamento da escola dos operários e seus filhos pelo número de estabelecimentos de ensino registrado pela impressa local. Todavia, constata-se pela via das contradições entre o capital e trabalho declarações ambíguas quanto o conteúdo da educação dos operários e de seus filhos noticiada, no jornal $O$ Operário, pelo articulista João de Oliveira Camargo ao referir-se sobre, liberdade e o trabalho.

Educar o operário e os filhos dar-lhes a luz bendita da instrução, é obra mais meritória, mais santa, que se pode cumprir aos olhos de Deus, aos olhos dos homens, e imitar aquele eterno modelo de virtude, de perfeição, que se goza em dar a verdadeira divina as crianças, como a ave do céo dá o grão de trigo aos seus ternos pimpolhos que piam no ninho (O Operário, Anno III No 112 , $10 / 12 / 1911$, p. 1)

Embora, nessa fala, haja certa contradição com o pensamento libertário, pelo fato de atribuir a educação e instrução enquanto uma obra digna de apreço aos olhos de Deus, não podemos deixar de registrar a importância dada à instrução, cuja finalidade era eliminar o caráter dualista marco visível na instrução escolar desde os tempos remotos. Acrescenta ainda, o articulista, que essa tinha por finalidade contribuir para a perfeição da terra, dos trabalhadores e do cidadão. Salienta que "a educação, como o homem, deve ter dois ensinamentos: moral e religioso". "A educação deve ter dois ensinamentos: ensinamentos de personalidade que trouxe a vida: e o ensinamento de seus deveres para com a sociedade em que vive" (O Operário, Anno III no 112, 10/12/1911, p. 2)

Nessa luta pela instrução, o jornal $O$ operário já trazia em um dos seus artigos, Democracia e instrução, assinado por Baptista de Santis, que o século XX seria o século "da mais pura democracia" e que essa seria obtida "pela instrução".

\footnotetext{
Será o século da mais pura democracia, e pela qual os homens conscientes, desimpedidos das lutas mesquinhas que lhes aviltam a condição social, erguer-se-ão à altura dum baluarte comum para a defesa da Verdade - numa igualdade de luz, caindo com deslumbramentos portentosos da razão sobre as trevas ignominiosas da obsessão do erro.

Será o século, portanto, da independência racional, amando-se a liberdade, não pelo que ela tem de subversiva à ordem pública, mas pelo que ela encerra de verdadeiro como prerrogativa dum cidadão apto, sem coação de moléstias nervosas, de preconceitos sociais e religiosos, e, sobretudo, sem as peias da ignorância. Mas isso pela instrução (O Operário, Anno II, $\mathrm{n}^{\circ}$ 66, de 01/01/1911, p. 2)
}

Nesse artigo é possível verificar, dentre outros aspectos, o ideal libertário proposto pela educação anarquista, em cuja mediação a escola aparece como sendo uma das formas institucionalizadas que instrui o operário para alcançar sua "independência racional". Tal independência, provinda da democracia do século $\mathrm{XX}$, em que os homens serão mais 
conscientes e defensores da verdade e da razão, proporcionaria a esse homem (operário) a libertação de toda sorte de ignorância.

$\mathrm{O}$ artigo ressalta, ainda, que no século $\mathrm{XX}$ a sociedade voltada para o progresso e para o bem-estar da humanidade terá como referência "a cultura racional do Bem”, cujo resultado é igualdade social, em que a razão prevalecerá sobre "as trevas ignominosas da obsessão do erro". A liberdade, segundo o articulista, resultará na sua independência racional, desde que esteja instruído na "a cultura racional do Bem" o que "efetivaria" sua liberdade e possibilitaria respeitar as normas de convivência social, desde que a base dessa instrução fosse norteada pelos princípios democráticos, que deveriam ser aprendidos pela razão. Assim sendo, a instrução aparece como fator fundamental para as conquistas dos trabalhadores, no início do século XX.

O "cidadão do futuro", tendo como referência a instrução integral que o prepara para a vida intelectual e para o trabalho, chegará, segundo o articulista, a conquista dos bens culturais providos da ciência e da arte, o que possibilitara a contrapor-se ao uso da ciência pela burguesia ${ }^{4}$ através da palavra falada ou escrita. A instrução integral condena a ciência que perverte o seu uso pelo doutrinamento e oprime em vez de libertar. Segundo Santis, esse cidadão "familiarizado com o seu código civil, (...) ilustrado pelas conquistas soberana das ciências e artes, ele avultar em todas as esferas sociais, como homem de seu século, isto é, forte no corpo, forte no espírito, e, mais ainda, em seus ideaes que saberá defender pela palavra ou pela penna, como esclarecido que será, sem dar satisfacções de conveniências a quem quer que seja, senão que a si mesmo pelos seus actos livres" (O Operário, Anno II, nº 66, de 01/01/1911, p. 2).

Outro aspecto indicado pelo articulista é sobre o enobrecimento do homem através da instrução, que não só nobilita o homem (o operário), mas o considera social, mais ilustrado, possibilitando-o a aceitar e compreender as coisas da fé pela razão.

Nesse dia teremos o homem ideal, que pouco os importará com o socialismo sendo elle mesmo o operário mais illustrado, e que pouco ainda se envolverá com a metapfísica da religião, porque compreenderá também que a fé, como virtude, se acceita pela razão, de ser respeitada, e se aceita pelo coração, mas que respeitada deve ser apoiada. Mas, isso pela instrucção ainda, visto que só por ele o homem se nobilita, e impõe-se à consideração social (O Operário, Anno II, nº 66, de 01/01/1911, p. 2)

Por fim, o artigo acena para o valor da instrução pública como condição primeira para a elevação da sociedade, verdadeiramente, democrática. Provavelmente, esse era o ideal do regime republicano: formar o cidadão no mundo moderno. Santis enuncia o que provavelmente já estava ocorrendo em São Paulo, que muito provavelmente estivesse se referindo a reforma educacional de Caetano de Campos de 1890, poucos meses após a proclamação da República.

A luta pela redução da jornada de trabalho e suas conseqüências para educação já era uma prerrogativa presente na gênese do movimento operário internacional desde em 1894 (Cf. ANDREUCCI,1989). No Brasil os socialistas já se posicionaram ao adotarem posições da II Internacional (Cf. HARDMAN; LEONARDI, 1991), isso é constatado na greve de 1904, no Rio de Janeiro e em São Paulo, em que reivindicava-se a diminuição da jornada de trabalho para 8 horas, em que participaram desse movimento os tecelões e ferroviários de Sorocaba (KOVAL, 1982). No Primeiro Congresso Operário em 1906, essas reivindicações tornavam mais clara enquanto condição necessária para o bem-estar do trabalhador em vários aspectos inclusive a facilitação para o estudo e a educação. 
Considerado que a redução de horas de trabalho tem influência sobre a necessidade do bem-estar, aumentando o consumo e daí a produção; que por essa razão, e ainda por diminuir o trabalho cotidiano, a desocupação diminui e o salário tenderá a subir; que o descanso facilita o estudo, a educação associativa, a emancipação intelectual e combate o alcoolismo, fruto do excesso de trabalho, embrutecedor e exaustivo (PINHEIRO; HALL, 1979: 28-29, vol. I, p. 51).

Os operários percebem a importância das escolas, cuja finalidade era de alfabetizar o trabalhador, por um lado, mas que isso não estava sendo possível em detrimento da duração da jornada de trabalho, que impedia a freqüência nos estabelecimentos de ensino. Situação essa que valia não só para os adultos, como também para os menores que cumpriam a mesma jornada de trabalho.

As fábricas de tecidos Santa Maria e Santa Rosália trabalham até oito e meia da noite (...), a de Nossa Senhora da Ponte até às 7 h, a Fábrica de Chapéus até às $5: 30 \mathrm{~h}$ da tarde.

As escolas noturnas criadas e mantidas pelo governo do Estado, segundo o regulamento, devem abrir-se às 6 horas da tarde, fechando-se às 9 da noite (O Operário, Anno, II, nº 53, 02/10/1910, p. 1).

Estes horários, e a forma como estava organizado o trabalho, inviabilizava a freqüência operária nas escolas, não só pelo excesso de horas, como também, pela fadiga que impossibilitava um aproveitamento satisfatório. Para a frequiência adequada na escola o proletariado luta pela redução da jornada de trabalho, o que seria uma das principais condições para o estudo e a educação. Embora nesse período as conquistas pela diminuição das horas de trabalho não fossem efetivadas, possibilitou o aumento de freqüência operária nas escolas, fato confirmado pelo jornal $O$ operário, especialmente as escolas noturnas incentivadas pela maçonaria.

\section{CONSIDERAÇÕES FINAIS}

Verificou-se, sumariamente, que a educação, vista pelas associações sindicais, na cidade de Sorocaba, passa por alguns momentos que estão condicionados ao processo de industrialização e pela imigração. Quanto ao primeiro, trouxe novas formas de vida social para os seus moradores. Em meio a esse novo momento verificou-se situações de contradição e de resistências não entendidas unicamente pelo viés econômico, mas pelos interesses de classes anunciados através da imprensa operária local. No processo de industrialização é notável que os anarcossindicalistas, quanto às relações de trabalho, caracterizam através da imprensa a situação vivida pelos trabalhadores e seus filhos sob a ótica das relações sociais com os meios de produção e pela obrigatoriedade da venda do único bem que possuíam a força de trabalho. Verificou-se as contradições entre capital e trabalho no cotidiano, local em que se desenvolveram algumas das mais, senão as mais, relevantes disputas sociais. Tal fato provocou no modo de vida da classe trabalhadora acontecimentos diversos, vivenciados através da experiência do trabalho e da consciência que tinham de si. O que vimos, porém, é que os anarcossindicalistas denunciaram as incongruências entre capital e trabalho demonstrada através da consciência dos articulistas da imprensa operária.

Sobre a imigração essa possibilitou à cidade novas idéias oriundas dos socialistas e anarquistas, que proporcionaram ao meio operário, principalmente os anarcossindicalistas, o impulso para a organização operária em sindicatos onde se processava a luta de classe e a conquista pelo direito a educação. 
Por fim, constatou-se, através dos anarcossindicalistas, a consciência que tinham da educação quando retomam os ideais libertários, cuja referência está na educação integral e a transformação social através das formas institucionalizadas de instrução operária. Esse procedimento possibilita à classe operária que alcance sua "independência racional", compreensão essa oriunda da democracia do século XX, em que os homens serão mais conscientes, defensores da verdade e da razão, o que propicia a esse homem (operário) a libertação de toda sorte de ignorância formando-o para ser o "cidadão do futuro". Constatouse, ainda, a intencionalidade da formação integral como preparação para a vida intelectual e a vida para o trabalho, fator fundamental para as conquistas do início do século XX.

\section{REFERÊNCIA}

ALMEIDA, Aluísio de. Sorocaba: 3 séculos de história. Itu, SP: Otton, 2002

ANDREUCCI, Franco. "A difusão e a vulgarização do marxismo". In: HOBSBAWM, Eric et. al. História do marxismo: o marxismo da época da segunda Internacional. Rio de Janeiro: Paz e Terra, 1989. Vol. II

ARAÚJO NETO, Adalberto Coutinho de. Sorocaba operária: ensaio sobre o início do movimento operário em Sorocaba 1897-1920. Sorocaba, SP: LINC, 2005

BAKUNIN, Mikhail. A instrução integral. São Paulo, Imaginário, 2003

BARRUÉ, Jean. "Bakunin e a educação”. In: BAKUNIN, Mikhail. A instrução integral. São Paulo, Imaginário, 2003

BONADIO, Geraldo. Sorocaba: a cidade industrial. (Espaço urbano e vida social sob o impacto da atividade fabril). Sorocaba, SP: do autor, 2004

O Partido Democrata Social e o jornal “A conquista do Bem, 1897”. Sorocaba: Academia sorocabana de Letras, 1992

CARMO, Jefferson Carriello do. A fábrica têxtil em Sorocaba, imprensa operária e educação nos anos de 1889-1914. Ideação. Unioeste, Campus Foz do Iguaçu. V. 8 - nº 9, p. 23-37, 2006

CARVALHO, Rogério Lopes Pinheiro de. O Operário, edição fac-similar. Sorocaba, SP: Crearte, 2007

CAVALHEIRO, Carlos Carvalho. Salvadora!. Sorocaba, SP: Linc, 2001

HARDMAN, Foot; LEONARDI, Victor. História da indústria e do trabalho no Brasil: das origens aos anos 20. 2.ed. rev. São Paulo: Ática, 1991

KOVAL, Boris. História do proletariado brasileiro 1857 a 1967. São Paulo: Alfa-Omega, 1982

MARTINS, José de Souza. O cativeiro da terra. 2. ed. São Paulo: LECH, 1981

PINHEIRO, Paulo Sérgio; HALL, Michael M.. A classe operária no Brasil, 1989-1930. São Paulo: Alfa-Omega, 1979

RIBEIRO, Maria Alice Rosa. Condições de trabalho na indústria têxtil paulista (18701930). São Paulo: Hucitec; UNICAM, 1998

RODRIGUES, Edgar. Socialismo e sindicalismo no Brasil (1675-1913). Rio de Janeiro: Laemmert, 1969 
RODRIGUES, Leôncio Martins. Sindicalismo e sociedade. São Paulo: Difusão Européia do Livro, 1968

SILVA, Sergio. Expansão cafeeira e origens da indústria no Brasil. São Paulo: Alga Omega, 1976

\section{FONTES PRIMÁRIAS:}

\section{JORNAIS}

Jornal Gazeta do Além Ponte, $(1992, ?)$

Jornal O Operário (1909-1913)

Jornal A Voz do Povo (1895 - 1897)

\section{Almanaques}

SILVA, Maria Vieira (Org.). Almanach de Sorocaba, 1903. Ed. Fac-similar, Taquarituba, São Paulo: Nsssib Etefano, 2007

SILVA, Maria Vieira (Org.). Almanach de Sorocaba, 1904. Ed. Fac-similar, Taquarituba, São Paulo: Nsssib Etefano, 2007

\section{REVISTAS}

Revista O fim do século (1897)

\footnotetext{
${ }^{1}$ Trabalho apresentado no VIII CONGRESO IBEROAMERICANO DE HISTORIA DE LA EDUCACIÓN LATINOAMERICANA: Contactos, cruces y luchas en la historia de la educación latinoamericana Buenos Aires, 30 de octubre al 2 de noviembre de 2007.

${ }^{2}$ Cf. Anúncios, Sorocaba, 10 out.1879; Diário de Sorocaba, 11/05 1883, 9/10/1884; 12/12/1884; 7/12/1886 e 5/04/1889.

${ }^{3}$ Estamos utilizando a edição fac-similar organizada por Rogério Lopes Pinheiro de Carvalho, 2007.

${ }^{4}$ Segundo, Bakunin, (...) a organização econômica e política da sociedade foi tal que só os burgueses puderam instruir-se, que a ciência não existiu senão para eles, e que o proletariado encontrou-se condenado a uma ignorância forçada" . BARRUÉ, Jean. Bakunin e a educação. In: BAKUNIN, Mikhail. A instrução integral. São Paulo: Imaginário, 2003, p. 16-17.
}

Artigo recebido em: 27/04/10

Aprovado em: 07/07/10 